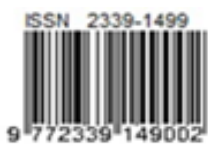

\title{
Perancangan Aplikasi Penyedia Informasi Perguruan Tinggi Bagi Pelajar SMA/ Sederajat dengan Metode Participatory Design
}

\author{
William Reynaldo', Marihot Nainggolan ${ }^{2}$, Clara Theresia $^{3}$ \\ 1,2) Fakultas Teknologi Industri, Jurusan Teknik Industri, Universitas Katolik Parahyangan \\ Jl. Ciumbuleuit 94, Bandung 40141 \\ Email: williamreynaldo16@gmail.com , marihot.nainggolan@unpar.ac.id , claratheresia@unpar.ac.id
}

\begin{abstract}
Abstrak
Continuing study to higher education is an important thing for most of high school students, but there are still obstacles related to the information availability of higher education for high school students. These constraints can be divided into 3 categories, namely limited university information, limited department information, and limited registration information. Currently, there are university information apps, however those applications have not been able to overcome the three categories of obstacles faced. Thus, an design for application that can handle these problems. In this research, a design for application for information about higher education providers was conducted. The application design consists of 4 stages, started by determining needs using the focus group discussion method which involved 9 respondents and produced 23 needs. The second stage, determining design alternatives using the participatory design workshop method involving 8 respondents and producing 4 design alternatives, and selecting an alternative design involving 19 respondents. The third stage is making a high-fidelity prototype with the help of Adobe XD software. In the last stage, evaluation and improvement are carried out by considering the factors of usefulness, effectiveness, efficiency, learnability, and satisfaction. The result of this research is a design of application that provide information about university that meets aspects of functionality and usability. Those aspects including the usefulness factor $81.79 \%$, the effectiveness factor $82.14 \%$, the efficiency factor $82.14 \%$, the learnability factor $71.43 \%$, and the satisfaction factor $79.64 \%$. Based on these results, this application able to use and meets user needs.
\end{abstract}

Keywords: application design, interaction design, high school students, usability

\begin{abstract}
Abstrak
Melanjutkan studi ke pendidikan tinggi merupakan hal yang penting bagi sebagian besar siswa sekolah menengah, namun terdapat kendala terkait ketersediaan informasi perguruan tinggi bagi siswa SMA. Kendala tersebut dapat dibagi menjadi 3 kategori, yaitu informasi universitas terbatas, informasi jurusan terbatas, dan informasi pendaftaran terbatas. Saat ini sudah ada aplikasi penyedia informasi universitas, namun aplikasi tersebut belum mampu mengatasi ketiga kategori kendala yang dihadapi. Dengan demikian suatu desain aplikasi yang dapat menangani permasalahan tersebut. Pada penelitian ini dilakukan perancangan aplikasi informasi tentang penyelenggara pendidikan tinggi. Perancangan aplikasi ini terdiri 4 tahap yaitu dimulai dengan penentuan kebutuhan dengan metode focus group discussion yang melibatkan 9 responden dan menghasilkan 23 kebutuhan. Tahap kedua, penentuan alternatif desain menggunakan metode workshop desain partisipatif dengan melibatkan 8 responden dan menghasilkan 4 alternatif desain, lalu memilih desain alternatif yang melibatkan 19 responden. Tahap ketiga adalah membuat prototipe high-fidelity dengan bantuan software Adobe XD. Pada tahap terakhir dilakukan evaluasi dan perbaikan dengan mempertimbangkan faktor kegunaan, efektivitas, efisiensi, kemampuan belajar, dan kepuasan. Penelitian ini menghasilkan sebuah rancangan aplikasi yang memberikan informasi tentang perguruan tinggi yang memenuhi aspek fungsionalitas dan kegunaan. Aspek-aspek tersebut meliputi faktor kegunaan 81,79\%, faktor keefektifan $82,14 \%$, faktor efisiensi $82,14 \%$, faktor kemampuan belajar $71,43 \%$, dan faktor kepuasan $79,64 \%$. Berdasarkan hasil tersebut, aplikasi dapat digunakan dan memenuhi kebutuhan pengguna.
\end{abstract}

Kata kunci: desain interaksi, pelajar SMA/ sederajat, perancangan aplikasi, usabilitas 


\section{Pendahuluan}

Pendidikan lanjut merupakan suatu hal yang penting. Meskipun demikian, masih dijumpai beberapa permasalahan yang dialami oleh pelajar SMA/ sederajat. Permasalahan pertama adalah sulit menenrukan perguruan tinggi. Terdapat beberapa faktor dalam menentukan perguruan tinggi, faktor tersebut diantaranya kondisi ekonomi, perguruan tinggi, lokasi, lingkungan sekitar, dan promosi. (Sudarwati \& Tikwalau, 2014)

Permasalahan kedua adalah sulit menentukan jurusan perkuliahan. Menurut Putri (2018), hampir 45\% mahasiswa merasa salah dalam mengambil jurusan dan menurut Dekirty (2019), penyebab utama salah jurusan adalah kurangnya riset terhadap jurusan yang dipilih. Permasalahan terakhir adalah terbatasnya pengetahuan mengenai pendaftaran.

Untuk memastikan hal tersebut benar adanya, dilakukan studi pendahuluan pertama dengan metode wawancara kepada 12 responden (pelajar SMA/ sederajat kelas 2, kelas 3, dan mahasiswa salah jurusan). Adapun sebaran dari responden berasal dari SMAK 1 BPK Penabur, SMAK 1 Bina Bakti, SMA Alyosius, SMA 1 Margahayu, dan Universitas Kristen Maranatha, dengan 8 orang pelajar SMA kelas 3, 2 orang pelajar SMA kelas 2, dan 2 orang mahasiswa salah jurusan.

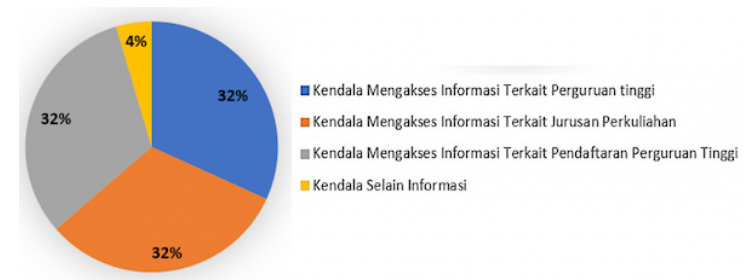

Gambar 1. Hasil studi pendahuluan pertama (kendala yang dihadapi pelajar SMA/ Sederajat)

Dapat diketahui dari Gambar 1, jika kendala yang dihadapi terbagi 4 dan didominasi oleh 3 kendala. Kendala pertama adalah mengakses informasi terkait perguruan tinggi. Kendala kedua adalah mengakses informasi terkait jurusan. Kendala terakhir adalah mengakses informasi terkait pendaftaran perguruan tinggi.

Studi pendahuluan kedua dengan metode kuesioner kepada 22 responden (mahasiswa). Didapati sebaran responden berasal dari beberapa perguruan tinggi dan jurusan yang bebeda.

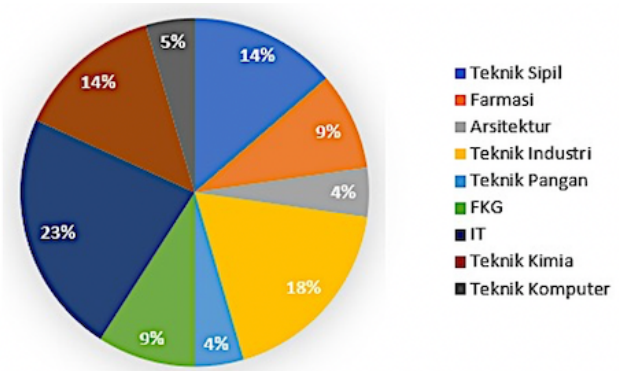

Gambar 2. Sebaran Jurusan Mahasiswa

Menurut hasil studi pendahuluan kedua, 9 dari 22 mahasiswa merasa dirinya salah jurusan. Bila dilihat dari Gambar 3, penyebab utama salah jurusan adalah kurangnya riset terhadap jurusan yang ingin diambil. Penyebab lainnya mahasiswa salah jurusan karena belum menemukan minat dan bakat, ikutikutan teman, dan keinginan dari orang tua.

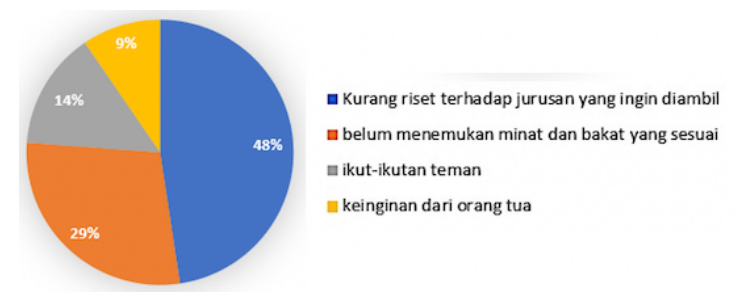

Gambar 3. Hasil studi pendahuluan kedua (penyebab mahasiswa salah jurusan)

Dari kedua hasil studi pendahuluan tersebut, seluruh responden menyatakan jika dirinya tertarik menggunakan aplikasi penyedia informasi perguruan tinggi. Aplikasi dinilai dapat menjadi salah satu solusi untuk mengatasi permasalahan pelajar SMA/ sederajat. Hal tersebut didukung oleh penyataan KOMINFO (2017) yang mengatakan jika $79,56 \%$ pelajar SMA/ sederajat telah menggunakan smartphone dan smartphone dapat dijadikan sumber informasi.

Saat ini, telah tersedia beberapa aplikasi penyedia informasi perguruan tinggi seperti goKampus, rencanaMu, Info Kuliah, dan lainnya. Walaupun sudah tersedianya aplikasi penyedia informasi perguruan tinggi, namun aplikasi tersebut belum dapat menyelesaikan keseluruhan kendala yang dihadapi pelajar SMA/ sederajat. Sebagai contoh, aplikasi goKampus hanya menyediakan informasi perguruan tinggi swasta, aplikasi rencanaMu tidak menyediakan informasi jurusan, dan aplikasi Info Kuliah hanya menyediakan informasi perguruan tinggi negeri. 
Dikarenakan hal tersebut, dibutuhkan suatu aplikasi yang menyediakan informasi secara lengkap. Rancangan aplikasi harus memenuhi aspek functionality dan juga usability. Aspek functionality melihat apakah fungsi aplikasi telah sesuai dengan tujuannya dan aspek usability melihat faktor usefulness, efktivitas, efisiensi, learnability, dan satisfaction (Rubin \& Chisnell, 2008).

\section{Metodologi}

\section{Hierarchy of User Needs}

Hierarchy of product atau yang lebih dikenal dengan sebutan hierarchy of user needs adalah susunan kepentingan yang dibutuhkan dalam melakukan suatu perancangan produk. Hierarchy of user needs digambarkan dengan segitiga yang terbagi dalam 3 buah tingkatan seperti yang terlihat pada Gambar 4. Tingkatan paling dasar adalah functionality, lalu selanjutnya usability, dan tingkat teratas adalah pleasure.

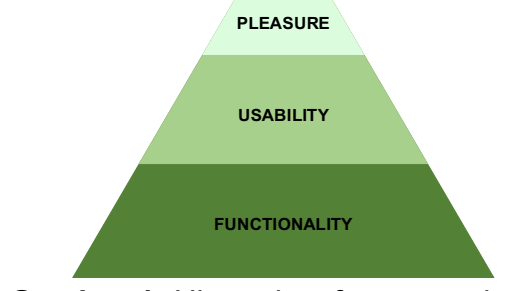

Gambar 4. Hierarchy of user needs Sumber: (Jordan, 2000)

Dalam hierarchy of user needs, tingkatan atas dapat terpenuhi jika tingkatan sebelumnya telah terpenuhi. Seperti contohnya, aspek usability dapat terpenuhi jika aspek functionality telah terpenuhi. (Jordan, 2000).

\section{Participatory Design}

Participatory design memiliki tujuan untuk melibatkan pengguna dalam proses desain, dengan demikian hal yang diinginkan pengguna dapat terpenuhi dengan lebih baik. Participatory design dibutuhkan, karena pengguna perlu memiliki rasa kepemilikan supaya dapat meningkatkan perancangan/ desain produk (Sakai, et al., 2012).

Participatory design memiliki beberapa kelebihan, diantaranya menghindari terjadinya kesalahan, menambah penglihatan/ perbedaan sudut pandang, membuat pengguna memiliki rasa kepemilikan dari rancangan desain, mengurangi biaya dengan mengurangi perubahan, dan semakin banyak ide untuk dikembangkan. Selain kelebihan dari participatory design, terdapat juga beberapa kekurangan, diantaranya membutuhkan waktu yang lebih lama, munculnya resiko perdebatan dalam perancangan, terlalu banyaknya sudut pandang, sulit untuk mencapai suatu kesepakatan, dan memungkinkan munculnya konflik kepentingan (Demirbilek, 1999).

\section{Proses Desain Interaksi}

Tujuan dari melakukan desain interaksi adalah mengurangi aspek negatif dan meningkatkan aspek positif dari suatu produk. Terdapat 3 hal yang perlu diperhatikan, pertama pengembang harus melibatkan pengguna dalam proses perancangan. Kedua, menentukan secara spesifik tujuan usability dan user experience. Terakhir, memperhatikan iterasi setiap proses yang terjadi.

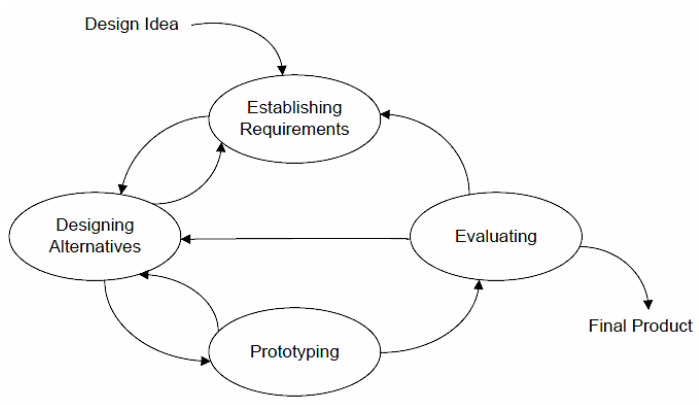

Gambar 5. Siklus Proses Desain Interaksi Sumber: (Preece et al., 2015)

Di dalam proses desain interaksi, terdapat empat tahapan, diantaranya identifikasi kebutuhan, membuat alternatif konsep, pembuatan prototipe, dan eveluasi prototipe (Christina et al. (2014), Preece et al. (2015)). Tahapan-tahapan tersebut lebih jelasnya dapat dilihat pada Gambar 5 (Preece et al., 2015).

\section{Usability Testing}

Metode usability testing mengacu pada pengukuran seberapa baik tingkat kemampupakaian (usability) dari produk yang dirancang. Menurut Rubin \& Chisnell (2008), faktor penilaian usability adalah usefulness, efficiency, affectiveness, learnability, satisfaction, dan accessibility. Tujuan dari usability testing sangat bermacam, tetapi biasanya meliputi 3 hal utama. Hal tersebut diantaranya mengidentifikasi masalah dalam desain produk atau layanan. Mencari dan menemukan permasalahan sehingga dapat 
melakukan perbaikan, dan terakhir mempelajari prilaku dan hal yang disukai dari pengguna (Moran, 2019).

Usability testing memiliki 3 elemen utama. Elemen tersebut diantaranya adalah fasilitator tugas-tugas, dan peserta. Fasilitator mempunyai tugas untuk memandu peserta untuk melewati tes. Fasilitator harus menjamin data yang diperoleh memiliki kualitas yang baik, valid, dan tidak mempengaruhi kebiasaan dari peserta. Tugas-tugas dalam usability testing adalah kegiatan realistis yang mungkin dilakukan peserta dalam kehidupan nyata. Peserta adalah pengguna dari produk atau layanan yang sedang dipelajari atau diamati. Langkah atau aliran informasi usability testing dapat dilihat pada Gambar 6 (Moran, 2019).

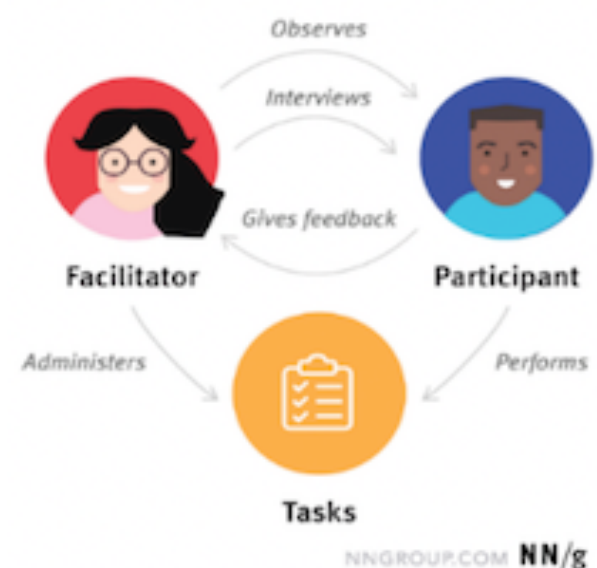

Gambar 6. Aliran informasi dari usability testing Sumber: (Moran, 2019)

\section{Metode USE Questionaire}

Metode USE Questionaire digunakan untuk melakukan perhitungan nilai usefulness dari produk/aplikasi. Metode USE questionnaire terdiri dari 30 pertanyaan dan 8 dari 30 pertanyaan tersebut dapat mewakili usefulness. Penilaian pada metode USE questionnaire memiliki rentang nilai 1 sampai 5 , dengan nilai 1 menandakan sangat tidak setuju dan nilai 5 menandakan sangat setuju (Putra \& Tanamal, 2020).

\section{Metode SUS (System Usability Scale)}

Metode SUS digunakan untuk melakukan perhitungan nilai satisfaction dari pengguna terhadap produk/aplikasi. Terdapat beberapa kelebihan dari metode SUS, diantaranya SUS lebih mudah dan lebih cepat jika dibandingan dengan metode lainnya (Thomas, 2013) dan penggunaan metode SUS membutuhkan responden lebih sedikit untuk mencapai kesimpulan yang benar (Brooke, 2013)

\section{Focus Group Discussion}

Menurut Afiyanti (2008), Focus group discussion merupakan metode yang mengandalkan perolehan informasi atau data melalui interaksi informan atau responden berdasarkan hasil diskusi dalam suatu kelompok yang berfokus untuk membahasan dan menyelesaikan permasalahan tertentu. Pada focus group discussion memiliki karakteristik jumlah individu yang bervariasi untuk satu kelompok diskusi. Satu kelompok diskusi dapat terdiri dari 4-8 individu atau 6-10 individu. Dalam satu kelompok diskusi, terdapat 1 fasilitator, 1 moderator, dan yang lainnya sebagai partisipan (Afiyanti, 2008).

Terdapat 3 tahapan yang perlu diperhatikan sebelum melakukan focus group discussion, diantaranya (Paramita \& Kristiana, 2013):

1. Persiapan FGD: dilakukan penentuan kelompok FGD, komposisi kelompok FGD, menentukan tempat diskusi FGD, menyiapkan undangan, dan menyiapkan Fasilitator. (Paramita \& Kristiana, 2013).

2. Pembukaan FGD: dilakukan dengan pengenalan setiap anggota, memberikan penjelasan mengenai $F G D$, memberikan penjelasan mengenai pembuatan suatu aplikasi, dan menekankan jika dibutuhkan pendapat dari semua peserta dalam proses FGD (semua perserta bebas mengeluarkan pendapatnya).

3. Pelaksanaan atau teknik pengelolaan FGD: (1) fasilitator menanyakan kebutuhan untuk aplikasi. (2) notulen mencatat kebutuhan tersebut. (3) fasilitator mulai menggali dan menanyakan kembali 1 per 1 kebutuhan peserta dalam bentuk pertanyaan. (4) notulen mencatat inti dari kebutuhan yang telah digali. (5) fasilitator menanyakan dan memastikan jika tidak ada kebutuhan yang terlewat. (6) bila seluruh peserta setuju mengenai kebutuhan, maka FGD selesai. Jika ada salah 1 peserta yang tidak setuju, maka dilakukan diskusi kembali mengenai kebutuhan tersebut.

\section{Penyesuaian}

Penyesuaian bertujuan untuk menormalkan waktu siklus dikarenakan kecepatan yang tidak 
wajar dilakukan oleh seorang operator. Dalam hal ini, konsep wajar berartikan operator dapat menyelesaikan suatu tugas dengan usaha tidak berlebihan selama proses kerjanya. Penyesuaian dibutuhkan untuk melakukan perhitungan waktu normal (Sutalaksana et al., 2016).

Menurut Sutalaksana et al. (2016), waktu normal adalah waktu penyelesaian pekerjaan yang diselesaikan oleh pekerja dalam kondisi wajar dan dengan kemampuan rata-rata. Waktu normal dibutuhkan untuk mengetahui waktu normal pengerjaan tugas usability testing oleh responden. Terdapat beberapa metode penyesuaian, diantaranya metode persentase, Shumard, Westinghouse, dan Objektif.

\section{Hasil dan Pembahasan}

Identifikasi kebutuhkan pengguna dilakukan menggunakan metode focus group discussion (FGD). Pemilihan metode FGD dikarenakan adanya interaksi antar partisipan yang menghasilkan kekayaan data atau informasi kebutuhan pengguna. FGD dilakukan sebanyak 2 kali untuk 2 kelompok yang berbeda. Kelompok FGD ke-1 beranggotakan pelajar SMA kelas 2 dan kelas 3. Kelompok FGD ke-2 beranggotakan Mahasiswa salah jurusan.

FGD ke-1 beranggotakan 7 orang, dengan peserta 5 orang yaitu 2 orang pelajar SMA kelas 3 di SMA 1 Margahayu, 2 orang pelajar SMA kelas 2 di SMA Bina Bakti 1, dan 1 orang pelajar telah lulus SMA dan mencoba memasuki perguruan tinggi, fasilitator 1 orang, dan notulen 1 orang. Gambar 7 menunjukkan proses penggalian kebutuhan pertama menggunakan metode FGD. FGD ini menghasilkan total 34 kebutuhan pengguna.

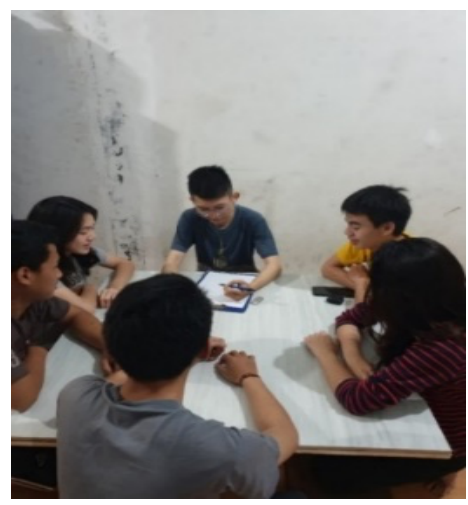

Gambar 7. Proses penggalian kebutuhan pertama menggunakan FGD
FGD kedua beranggotakan 6 orang, dengan peserta 4 orang, yang terdiri dari 1 orang Mahasiswa dari UNPAR, dan 2 orang Mahasiswa dari Universitas Kristen Maranatha, dan fasilitator serta notulen.

Gambar 8 menunjukkan proses penggalian kebutuhan ke-2 menggunakan metode FGD yang menghasilkan total 27 kebutuhan pengguna.

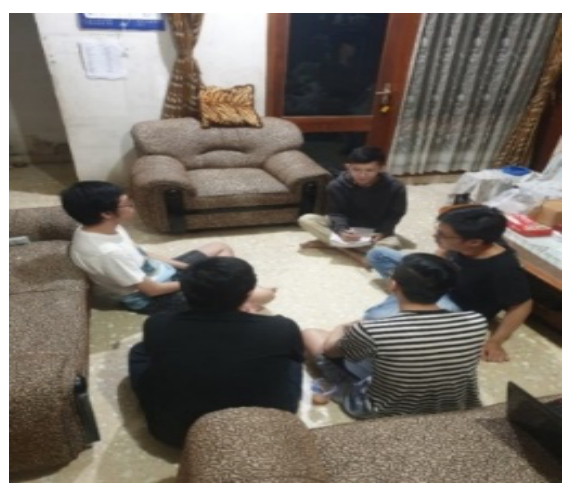

Gambar 8. Proses penggalian kebutuhan kedua menggunakan FGD

Tabel 1. Rekapitulasi kebutuhan pengguna kategori informasi perguruan tinggi

\begin{tabular}{|c|c|}
\hline No. & Rekapitulasi Kebutuhan \\
\hline 1 & $\begin{array}{l}\text { Aplikasi mampu menunjukkan informasi } \\
\text { perguruan tinggi yang ada di Indonesia, } \\
\text { peringkat, dan rekomendasi perguruan tinggi } \\
\text { dari aspek tertentu seperti lokasi, peringkat, } \\
\text { dan lainnya }\end{array}$ \\
\hline 2 & $\begin{array}{l}\text { Aplikasi mampu menyediakan informasi } \\
\text { perkiraan biaya masuk, biaya per semester, } \\
\text { dan biaya per sks secara rinci }\end{array}$ \\
\hline 3 & $\begin{array}{l}\text { Aplikasi mempu membandingkan informasi } \\
\text { perguruan tinggi } 1 \text { dengan perguruan tinggi } \\
\text { yang lain dengan memperlihatkan beberapa } \\
\text { aspek seperti biaya. }\end{array}$ \\
\hline 4 & $\begin{array}{l}\text { Aplikasi dapat membantu memperlihatkan } \\
\text { informasi beasiswa yang tersedia dan } \\
\text { mempermudah mengetahui informasi } \\
\text { beasiswa seperti persyaratannya. }\end{array}$ \\
\hline 5 & $\begin{array}{l}\text { Aplikasi mampu menyediakan sumber } \\
\text { informasi yang berasal dari mahasiswa } \\
\text { melalui forum/ testimoni/ penjelasan/ review } \\
\text { dari mahasiswa terkait perguruan tinggi. }\end{array}$ \\
\hline 6 & $\begin{array}{l}\text { Aplikasi mampu memberikan informasi } \\
\text { mengenai fasilitas yang dimiliki oleh } \\
\text { perguruan tinggi dan jurusannya seperti } \\
\text { lahan parkir, kantin, laboratorium, ruang } \\
\text { kelas, dan lainnya, serta memperlihatkan } \\
\text { privilege fasilitas dari setiap jurusan }\end{array}$ \\
\hline 7 & $\begin{array}{l}\text { Aplikasi menyediakan informasi yang selalu } \\
\text { diperbaharui dan dapat dipercaya }\end{array}$ \\
\hline 8 & $\begin{array}{l}\text { Aplikasi memiliki halaman chat untuk } \\
\text { menanyakan informasi dengan pihak } \\
\text { perguruan tinggi atau mahasiswa }\end{array}$ \\
\hline 9 & $\begin{array}{l}\text { Aplikasi memberikan informasi kontak } \\
\text { perguruan tinggi yang mudah diakses }\end{array}$ \\
\hline 10 & $\begin{array}{l}\text { Aplikasi mampu mempercepat respon dari } \\
\text { perguruan tinggi untuk memperoleh informasi }\end{array}$ \\
\hline
\end{tabular}


Tabel 1 terdiri dari 10 kebutuhan yang telah direkapitulasi berdasarkan kategori kendala. Sedangkan tabel 2 memaparkan rekapitulasi kebutuhan pengguna dengan kategori jurusan perkuliahan, dan tabel 3 mengenai Rekapitulasi kebutuhan pengguna kategori pendaftaran perguruan tinggi.

Tabel 2. Rekapitulasi kebutuhan pengguna kategori jurusan perkuliahan

\begin{tabular}{|c|l|}
\hline No. & \multicolumn{1}{|c|}{ Rekapitulasi Kebutuhan } \\
\hline 1 & $\begin{array}{l}\text { Aplikasi mampu memberikan informasi lebih } \\
\text { dalam mengenai hal-hal yang akan dipelajari } \\
\text { pada jurusan tersebut dan memberikan } \\
\text { informasi jurusan yang ada pada setiap } \\
\text { perguruan tinggi beserta akreditasnya. }\end{array}$ \\
\hline 2 & $\begin{array}{l}\text { Aplikasi mampu melakukan perbandingan } \\
\text { informasi jurusan 1 dengan jurusan lainnya } \\
\text { seperti deskrispi, hal yang dipelajari, profesi } \\
\text { pekerjaan. }\end{array}$ \\
\hline 3 & $\begin{array}{l}\text { Aplikasi mampu melakukan perbandingan } \\
\text { informasi jurusan yang sama pada perguruan } \\
\text { tinggi yang berbeda }\end{array}$ \\
\hline 4 & $\begin{array}{l}\text { Aplikasi mampu memberikan informasi } \\
\text { bidang profesi pekerjaan yang sesuai dalam } \\
\text { jurusan, informasi bidang pekerjaan dari } \\
\text { lulusan dan informasi tempat lulusan bekerja }\end{array}$ \\
\hline 5 & $\begin{array}{l}\text { Aplikasi mampu memberikan informasi } \\
\text { persentase kelulusan dalam jurusan tersebut }\end{array}$ \\
\hline 6 & $\begin{array}{l}\text { Aplikasi mampu memberikan informasi } \\
\text { jurusan rekomendasi/ terpopuler yang banyak } \\
\text { diminati di suatu perguruan tinggi }\end{array}$ \\
\hline 7 & $\begin{array}{l}\text { Aplikasi mampu menyediakan informasi } \\
\text { mengenai deskripsi ciri-ciri pelajar yang } \\
\text { sesuai untuk jurusan tersebut }\end{array}$ \\
\hline 8 & $\begin{array}{l}\text { Aplikasi mampu menyediakan informasi } \\
\text { terkait keahlian atau minat khusus yang } \\
\text { diharuskan ada untuk jurusan tersebut } \\
\text { (seperti harus kuat pada pelajaran apa) }\end{array}$ \\
\hline $\begin{array}{l}\text { Aplikasi menyediakan informasi passing } \\
\text { grade untuk dapat masuk suatu jurusan di } \\
\text { perguruan tinggi serta jumlah kuota } \\
\text { penerimaan jurusan tersebut }\end{array}$ \\
\hline
\end{tabular}

Tabel 3. Rekapitulasi kebutuhan pengguna kategori pendaftaran perguruan tinggi

\begin{tabular}{|c|l|}
\hline No. & \multicolumn{1}{|c|}{ Rekapitulasi Kebutuhan } \\
\hline 1 & $\begin{array}{l}\text { Aplikasi mampu menyediakan informasi } \\
\text { pendaftaran seluruh perguruan tinggi beserta } \\
\text { syarat, waktu, hal-hal yang harus } \\
\text { dipersiapkan, dan prosedur untuk } \\
\text { pendaftaran secara jelas dan lengkap }\end{array}$ \\
\hline 2 & $\begin{array}{l}\text { Aplikasi mampu menyediakan wishlist dan } \\
\text { reminder untuk update informasi terbaru dari } \\
\text { perguruan tinggi, seperti waktu pendaftaran } \\
\text { yang sudah mau berakhir. }\end{array}$ \\
\hline 3 & $\begin{array}{l}\text { Aplikasi mampu menyediakan informasi } \\
\text { setelah pendaftaran, seperti hal apa saja } \\
\text { yang dibutuhkan untuk ujian secara lengkap. }\end{array}$ \\
\hline 4 & $\begin{array}{l}\text { Aplikasi mampu memberikan notifikasi atau } \\
\text { pengingat informasi untuk waktu, tanggal, } \\
\text { dan informasi penting mengenai pendaftaran }\end{array}$ \\
\hline
\end{tabular}

Selanjutnya dilakukan pembuatan personas, storyboard, dan skenario. Personas merupakan tokoh fiktif yang menggambarkan karakteristik pengguna aplikasi. Storyboard dan skenario merupakan penggambaran kegiatan personas sebelum dan setelah menggunakan aplikasi.

\section{Penentuan Alternatif Desain}

Penentuan alternatif desain menggunakan metode participatory design workshop yang terdiri dari 3 tahapan, tahapan persiapan, pembukaan dan pelaksanaan yang dilakukan secara daring menggunakan media zoom.

Participatory design workshop memiliki anggota 9 orang, dengan peserta 8 orang dan fasilitator/ designer 1 orang. 8 orang peserta memiliki sebaran sebagai berikut, 4 pelajar SMAK 1 BPK Penabur, 1 Mahasiswa Universitas Kristen Maranatha, 1 orang Mahasiswa Binus Alam Sutera, 1 pelajar SMAN 1 Serang dan 1 pelajar yang sedang mencoba mendaftar perguruan tinggi.

Dalam participatory design workshop, fasilitator/designer merupakan peneliti. Gambar 9 menunjukkan proses pembuatan alternatif desain dengan metode participator design workshop.

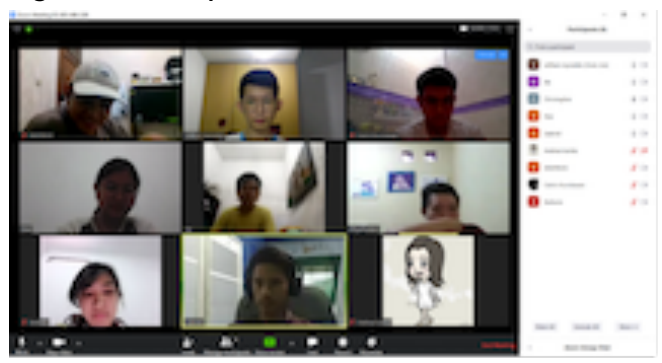

Gambar 9. Proses pembuatan alternatif desain dengan metode participatory design workshop

Tahapan pelaksanaan participatory design workshop, 8 peserta dibagi kedalam kelompok. Setiap kelompok beranggotakan 2 orang dengan tujuan peserta dapat melakukan brainstorming ketika melakukan perancangan aplikasi. Peserta dapat bertanya dan berdikusi dengan fasilitator/ designer selama proses perancangan berlangsung. Peserta diberikan waktu 1 jam 30 menit untuk melakukan perancangan alternatif desain.

Selanjutnya peserta diminta untuk melakukan presentasi terhadap alternatif desain yang dirancang. Total terdapat 4 alternatif desain yang dihasilkan dari proses participatory design workshop. 
Gambar 10 menunjukkan alternatif desain 1 yang memiliki ciri khas pada halaman utamanya yang menunjukkan semua fitur yang dimiliki pada aplikasi.

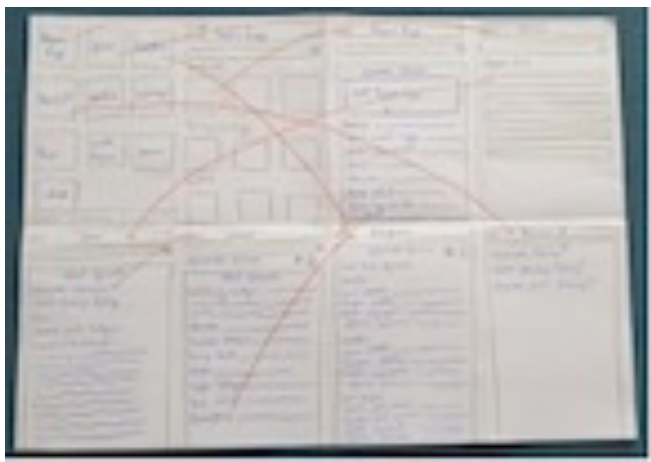

Gambar 10. Alternatif desain 1

Gambar 11 menunjukkan alternatif desain 2 yang memiliki ciri khas yaitu pembagian wilayah untuk fitur, news, rekomendasi, dan lainnya.

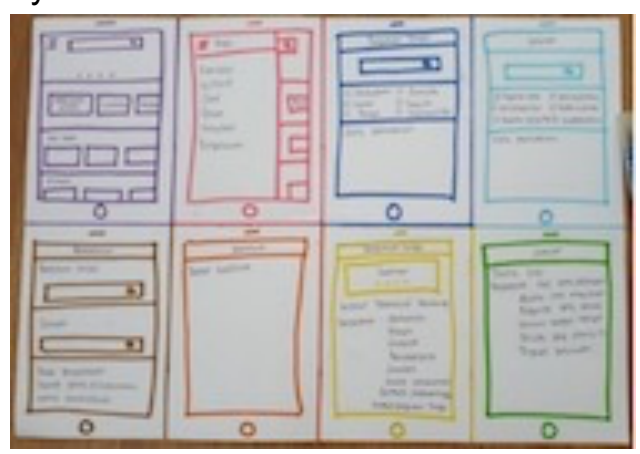

Gambar 11. Alternatif desain 2

Gambar 12 menunjukkan alternatif desain 3 yang memiliki ciri khas membagi informasi menjadi 2 bagian.
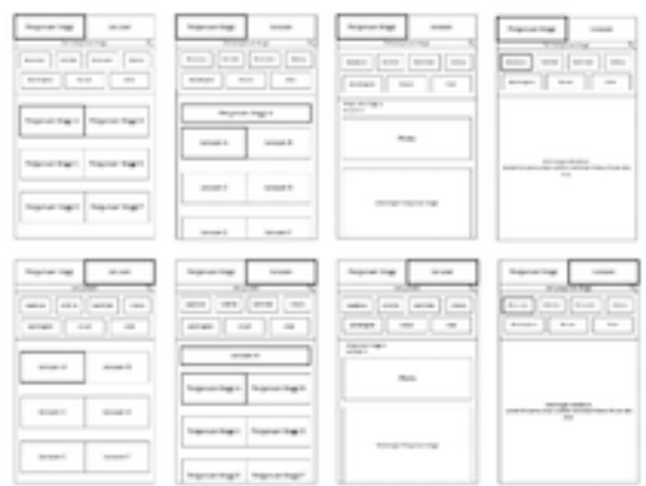

Gambar 12. Alternatif desain 3

Bagian pertama adalah perguruan tinggi dan bagian kedua adalah jurusan. setiap bagian memiliki fitur yang sama.

Sedangkan gambar 13 menunjukkan alternatif desain 4 dengan ciri khas adanya tab menu bagian bawah dan menu pada bagian atas.

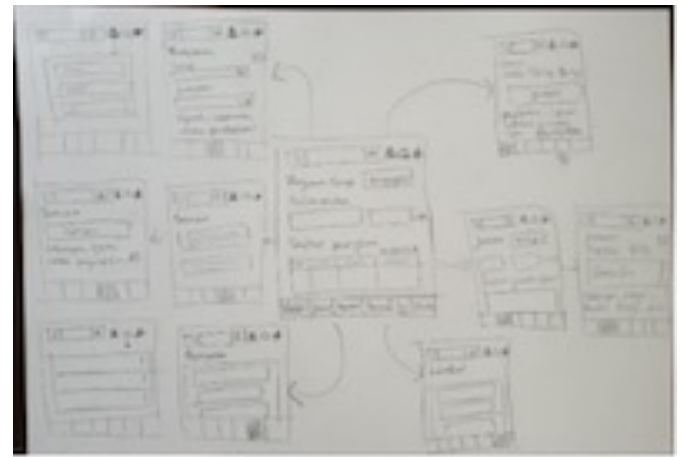

Gambar 13. Alternatif desain 4

Untuk menentukan alternatif desain terpilih, perlu dilakukan penilaian kuantitatif dan kualitatif untuk masing-masing alternatif desain (lihat tabel 4).

Tabel 4. Penilaian kualitatif

\begin{tabular}{|c|c|c|}
\hline No. & Kelebihan & Kekurangan \\
\hline \multicolumn{3}{|c|}{ Alternatif Desain Pertama } \\
\hline 1 & $\begin{array}{l}\text { Desain yang compact, } \\
\text { karena semua fitur } \\
\text { ditampilkan di halaman } \\
\text { utama }\end{array}$ & $\begin{array}{l}\text { Menyulitkan pengguna } \\
\text { kembali kehalaman } \\
\text { utama. Dikarenakan } \\
\text { harus menekan tombol } \\
\text { back secara berulang }\end{array}$ \\
\hline 2 & $\begin{array}{l}\text { Penjelasan dan alur } \\
\text { setiap fitur aplikasi } \\
\text { terlihat jelas }\end{array}$ & $\begin{array}{l}\text { Tidak menjelaskan } \\
\text { bagian bantuan, } \\
\text { notifikasi, dan setting }\end{array}$ \\
\hline 3 & $\begin{array}{l}\text { Alternatif desain } \\
\text { memperlihatkan detail } \\
\text { informasi sehingga } \\
\text { memperjelas aplikasi } \\
\text { yang akan dirancang }\end{array}$ & $\begin{array}{l}\text { Bagian filter dan sort } \\
\text { tidak terlihat, sehingga } \\
\text { pengguna tidak } \\
\text { mengetahui jika ada } \\
\text { fitur tersebut }\end{array}$ \\
\hline 4 & $\begin{array}{l}\text { Terdapatnya simbol- } \\
\text { simbol yang } \\
\text { mendukung interface } \\
\text { metaphors dari } \\
\text { pengguna. }\end{array}$ & - \\
\hline \multicolumn{3}{|c|}{ Alternatif Desain Kedua } \\
\hline 1 & $\begin{array}{l}\text { Memiliki desain yang } \\
\text { modern, dengan daftar } \\
\text { pilihan pada bagian } \\
\text { utama. }\end{array}$ & $\begin{array}{l}\text { Tidak menjelaskan } \\
\text { semua fitur yang ada, } \\
\text { hanya menjelaskan } \\
\text { beberapa fitur utama } \\
\text { saja. }\end{array}$ \\
\hline 2 & $\begin{array}{l}\text { Memperlihatkan bagian } \\
\text { filter dan sort saat } \\
\text { pemilihan fitur. Seperti } \\
\text { filter dan sort pemilihan } \\
\text { perguruan tinggi. }\end{array}$ & $\begin{array}{l}\text { Tidak ditemukannya } \\
\text { fitur perbandingan } \\
\text { jurusan dan perguruan } \\
\text { tinggi. }\end{array}$ \\
\hline 3 & & $\begin{array}{l}\text { Tidak tersedianya } \\
\text { tombol back kembali } \\
\text { kehalaman utama }\end{array}$ \\
\hline \multicolumn{3}{|c|}{ Alternatif Desain Ketiga } \\
\hline 1 & $\begin{array}{l}\text { Desain yang simpel } \\
\text { serta mengutamakan } \\
\text { hal yang menjadi } \\
\text { permasalahan, } \\
\text { perguruan tinggi dan } \\
\text { jurusan }\end{array}$ & $\begin{array}{l}\text { Tidak menjelaskan } \\
\text { secara detail setiap } \\
\text { bagian. Pengguna jadi } \\
\text { berasumsi informasi } \\
\text { lengkap atau informasi } \\
\text { tidak lengkap. }\end{array}$ \\
\hline 2 & $\begin{array}{l}\text { Terdapatnya semua } \\
\text { fitur pada bagian } \\
\text { perguruan tinggi dan } \\
\text { jurusan. }\end{array}$ & $\begin{array}{l}\text { Tidak terdapatnya fitur } \\
\text { notifikasi pada alternatif } \\
\text { desain }\end{array}$ \\
\hline
\end{tabular}


Tabel 4. Penilaian kualitatif (lanjutan)

\begin{tabular}{|c|c|c|}
\hline No. & Kelebihan & Kekurangan \\
\hline \multicolumn{3}{|c|}{ Alternatif Desain Ketiga } \\
\hline 3 & - & $\begin{array}{l}\text { Tidak terdapatnya } \\
\text { tombol back pada } \\
\text { alternatif desain. }\end{array}$ \\
\hline 4 & - & $\begin{array}{l}\text { Bagian filter dan sort } \\
\text { yang tidak terlihat, } \\
\text { memungkinkan } \\
\text { pengguna tidak } \\
\text { mengetahui jika ada } \\
\text { fitur tersebut }\end{array}$ \\
\hline \multicolumn{3}{|c|}{ Alternatif Desain Keempat } \\
\hline 1 & $\begin{array}{l}\text { Desain yang menarik, } \\
\text { dengan penjelasan pada } \\
\text { bagian utama dan pilihan } \\
\text { fitur pada bagian bawah }\end{array}$ & $\begin{array}{l}\text { Alur dari perpindahan } \\
\text { halaman kurang } \\
\text { terlihat, sehingga } \\
\text { menyulitkan pengguna } \\
\text { untuk mengetahui } \\
\text { alurnya. }\end{array}$ \\
\hline 2 & $\begin{array}{l}\text { Terdapatnya simbol- } \\
\text { simbol yang mendukung } \\
\text { interface metaphors dari } \\
\text { pengguna. }\end{array}$ & $\begin{array}{l}\text { Tidak menjelaskan } \\
\text { fungsi pengaturan } \\
\text { pada bagian kiri kolom } \\
\text { search. }\end{array}$ \\
\hline 3 & $\begin{array}{l}\text { Penjelasan setiap bagian } \\
\text { diperlihatkan dengan } \\
\text { cukup lengkap }\end{array}$ & $\begin{array}{l}\text { Tidak terdapatnya fitur } \\
\text { forum pada alternatif } \\
\text { desain. }\end{array}$ \\
\hline 4 & $\begin{array}{l}\text { Memiliki hampir semua } \\
\text { fitu yang ditampilkan } \\
\text { pada bagian bawah dan } \\
\text { beberapa dalam bentuk } \\
\text { simbol }\end{array}$ & $\begin{array}{l}\text { Tidak terdapatnya } \\
\text { tombol back pada } \\
\text { alternatif desain. }\end{array}$ \\
\hline 5 & - & $\begin{array}{l}\text { Bagian filter dan sort } \\
\text { yang tidak terlihat, } \\
\text { memungkinkan } \\
\text { pengguna tidak } \\
\text { mengetahui jika ada } \\
\text { fitur tersebut } \\
\end{array}$ \\
\hline
\end{tabular}

Penilaian kuantitatif dilakukan oleh 19 orang, 8 orang diantaranya berasal dari peserta participatory design workshop dan 11 lainnya adalah yang tidak terlibat participatory design workshop. Rekapitulasi hasil penilaian alternatif desain dapat dilihat pada Tabel 5.

Tabel 5. Rekapitulasi hasil penilaian alternatif desain

\begin{tabular}{|l|c|c|c|c|}
\hline \multirow{2}{*}{ Kategori } & \multicolumn{4}{|c|}{ Penilaian Alternatif } \\
\cline { 2 - 5 } & $\mathbf{1}$ & $\mathbf{2}$ & $\mathbf{3}$ & $\mathbf{4}$ \\
\hline $\begin{array}{l}\text { kebutuhan untuk } \\
\text { informasi perguruan } \\
\text { tinggi }\end{array}$ & 24,93 & 25,94 & 24,19 & 24,99 \\
\hline $\begin{array}{l}\text { kebutuhan untuk } \\
\text { informasi jurusan } \\
\text { perkuliahan }\end{array}$ & 25,08 & 24,03 & 23,88 & 25,88 \\
\hline $\begin{array}{l}\text { kebutuhan untuk } \\
\text { informasi pendaftaran } \\
\text { perguruan tinggi }\end{array}$ & 26,18 & 26,11 & 25,00 & 26,96 \\
\hline Total nilai & 76,19 & 76,08 & 73,07 & 77,83 \\
\hline
\end{tabular}

Dari Tabel 5, dapat diketahui jika alternatif desain 4 memiliki total nilai tertinggi sebesar 77.83. Pemilihan alternatif desain lebih berdasarkan penilaian kuantitatif. Hal tersebut dikarenakan penilian kuantitatif berdasarkan penilaian banyak orang (reponden), sedangkan penilaian kualitatif berdasarkan penilaian 1 orang (peneliti). Dikarenakan hal tersebut, maka alternatif desain 4 dijadikan dasar pembuatan konsep desain. Walaupun alternatif desain 4 menjadi dasar pembuatan konsep desain, tetapi kelebihan dari alternatif desain lain akan dipertimbangan.

Pembuatan konsep desain dibantu dengan software visio. Dapat dilihat hasil konsep desain pada Gambar 14.
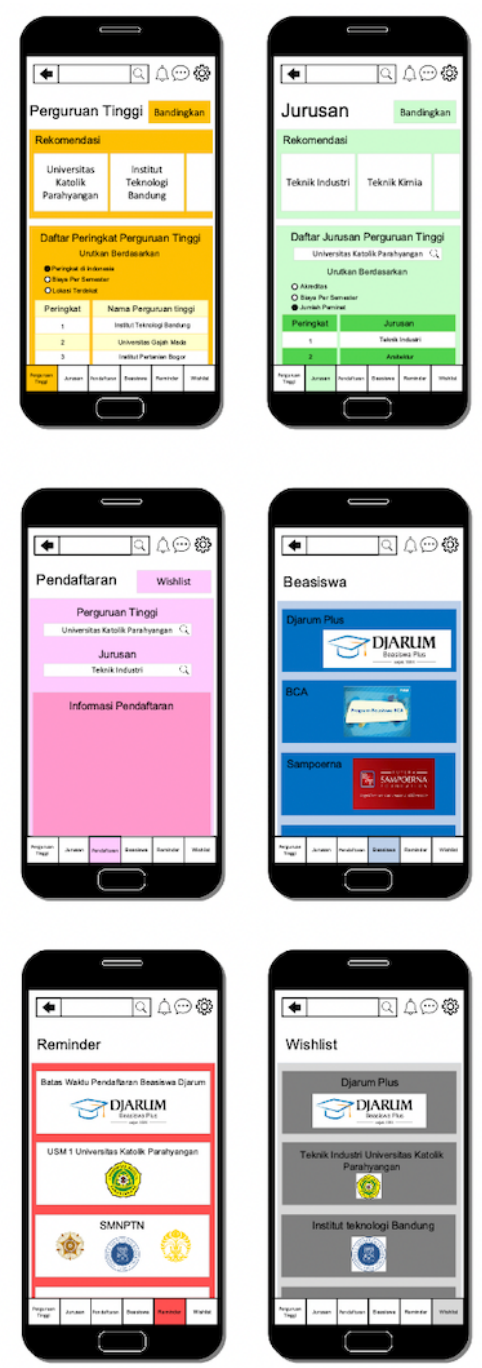

Gambar 14. Konsep desain

Dapat dilihat pada Gambar 14, konsep desain memiliki ciri khas alternatif desain 4. Hal tersebut dapat dilihat dengan adanya tab menu bagian bawah dan pada bagian atas terdapat kolom search, notifikasi, chat, dan pengaturan. Adapaun contoh kelebihan alternatif lain yang dipakai adalah fitur forum yang berasal dari alternatif desain 1 dan 2 . 


\section{Pembuatan Prototipe Aplikasi}

Prototipe aplikasi yang dirancang berjeniskan high-fidelity, yang berarti pengguna dapat berinteraksi secara langsung meskipun fitur dan data belum lengkap sepenuhnya. Pembuatan prototipe aplikasi menggunakan bantuan software adobe $\mathrm{xd}$.

Pemilihan adobe $x d$ sebagai aplikasi pembuatan prototipe, dikarenakan beberapa kelebihan yang dimikili adobe $x d$ seperti kemudahan akses dibeberapa platform, dapat terintegrasi dengan software adobe lainnya, dan biaya dari penggunaan software yang tidak berbayar. Tampilan prototipe aplikasi dapat dilihat pada Gambar 15.
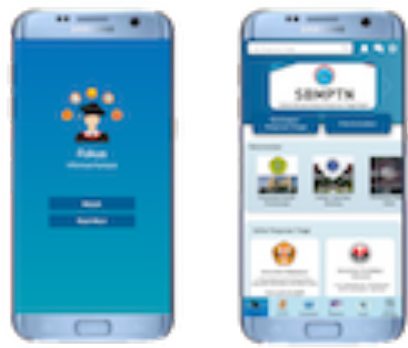

Gambar 15. Tampilan login dan halaman utama perguruan tinggi prototipe aplikasi

Gambar 15 tampilan halaman login dan halaman utama perguruan tinggi. Pada halaman utama perguruan tinggi terdapat fitur perbandingan perguruan tinggi dan filter dan urutkan. Bila dilakukan pemilihan salah satu perguruan tinggi, halaman akan menunjukkan profil perguruan tinggi, fasilitas, jurusan, pendaftaran, dan biaya perkuliahan. Dari hasil pemilihan perguruan tinggi tersebut, dapat dilakukan wishlist untuk setiap informasi. Seperti wishlist pendaftaran ataupun biaya perkuliahan.

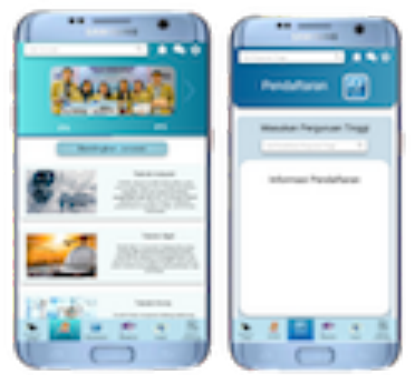

Gambar 16. Tampilan halaman utama jurusan dan halaman utama pendaftaran prototipe aplikasi

Gambar 16 menunjukkan halaman utama jurusan dan pendaftaran. Pada halaman utama jurusan, terdapat fitur pemilihan asal jurusan
IPA atau IPS. Jika dilakukan pemilihan IPA, maka akan menghasilkan pencarian seluruh jurusan IPA dan hal yang sama untuk IPS. Selain itu pada bagian jurusan, terdapat fitur perbandingan jurusan dan filter dan urutkan. Untuk perbandingan jurusan dapat melakukan perbandingan untuk jurusan yang sama atau jurusan yang berbeda.

Pada halaman utama pendaftaran, dapat melakukan pemilihan nama perguruan tinggi yang diinginkan. Jika dilakukan pemilihan perguruan tinggi, akan menghasilkan cara pendaftaran perguruan tinggi tersebut beserta dengan informasinya. Bagian pendaftaran terdapat fitur ingatkan tanggal penting/ reminder. Fitur ini berguna untuk mengingatkan tanggal pendaftaran. Tanggal yang diingatkan akan secara langsung terhubung dengan kalender smartphone pengguna.

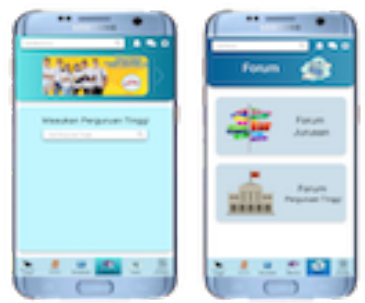

Gambar 17. Tampilan halaman utama beasiswa dan halaman utama forum prototipe aplikasi

Gambar 17 menunjukkan halaman utama beasiswa dan forum. Pada halaman tersebut dapat melakukan pemilihan beasiswa berdasarkan perguruan tinggi atau nama beasiswanya secara langsung. Jika dilakukan pemilihan, maka akan menghasilkan informasi terkait beasiswa tersebut. Bagian beasiswa memiliki fitur yang sama seperti pendaftaran, yaitu ingatkan tanggal penting/ reminder.

Pada halaman utama forum, terdapat pilihan forum jurusan dan forum perguruan tinggi. Forum jurusan berfungsi untuk melakukan diskusi sesama pengguna terkait topik jurusan. Forum perguruan tinggi berfungsi untuk melakukan diskusi sesama pengguna terkait topik perguruan tinggi. sebelum melihat tampilan utama forum, pengguna harus setuju dengan ketentuan forum. Hal tersebut untuk memberitahu pengguna, jika informasi pada forum belum tentu benar adanya (karena informasi berasal dari sesama pengguna). 


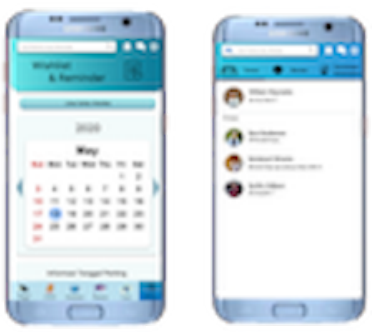

Gambar 18. Tampilan halaman utama wishlist dan reminder dan halaman chat prototipe aplikasi

Gambar 18 menunjukkan halaman utama beasiswa dan forum. Pada halaman utama wishlist dan reminder terdapat kalender yang memperlihatkan event tertentu. Kalender tersebut berisikan tanggal penting yang diingatkan. Selain itu terdapat juga menu daftar wishlist pengguna.

Pada halaman chat, terdapat daftar teman, daftar obrolan, dan permintaan pertemanan. Cara menambah teman dapat dilakukan melalui forum atau melakukan invite secara langsung. Pengguna dapat melakukan obrolan jika permintaan pertemanan telah disetujui. Hal tersebut untuk menjamin privacy dari pengguna aplikasi penyedia informasi perguruan tinggi.

\section{Evaluasi prototipe aplikasi}

Evaluasi prototipe aplikasi dengan melihat faktor usability. Faktor usability yang digunakan adalah usefulness, efektivitas, efisiensi, learnability, dan satisfaction (Rubin \& Chisnell, 2008). Evaluasi dilakukan kepada 7 orang responden, dengan 1 responden berasal dari Universitas Katolik Parahyangan, 1 responden dari SMA Trinitas, 1 responden berasal dari SMA ANgkasa Lanud Sulaiman, 1 responden berasal dari SMAN 1 Margahayu, 2 responden berasal dari SMAK 1 Bina Bakti, dan 1 responden berasal dari SMAK 1 BPK Penabur Holis Bandung.

Evaluasi usability menggunakan metode usability testing. Dalam melakukan usability testing, responden diminta menyelesaikan tugas (task completion) yang diberikan. Ketika responden melakukan tugas dan target tugas, peneliti mengamati waktu penyelesaian tugas dan target tugas responden serta melihat seberapa banyak responden yang dapat menyelesaikan tugas tanpa melakukan kesalahan. Daftar tugas dapat dilihat pada Tabel 6.
Tabel 6. Daftar tugas usability testing

\begin{tabular}{|c|l|}
\hline No. & \multicolumn{1}{|c|}{ Daftar Tugas } \\
\hline 1 & Login dan lakukan pengecekkan profile \\
\hline 2 & $\begin{array}{l}\text { Cari Perguruan tinggi swasta terbaik di } \\
\text { Indonesia dan lihat serta jadikan wishlist } \\
\text { informasi biaya perkuliahan di UNPAR }\end{array}$ \\
\hline 3 & $\begin{array}{l}\text { Cari dan lihat (2) informasi beasiswa di } \\
\text { Universitas katolik Parahyangan }\end{array}$ \\
\hline 4 & $\begin{array}{l}\text { Berikan Komentar pada forum "jurusan apa sih } \\
\text { yang lagi hot sekarang ini?" serta jadikan } \\
\text { teman salah satu orang pada forum tersebut } \\
\text { dan lakukan obrolan. }\end{array}$ \\
\hline 5 & $\begin{array}{l}\text { Cari jurusan teknik industri swasta terbaik di } \\
\text { jawa barat dan lihat informasi pembelajaran } \\
\text { Teknik Industri UNPAR }\end{array}$ \\
\hline 6 & $\begin{array}{l}\text { Lakukan perbandingan Jurusan Teknik Industri } \\
\text { dan perbandingan Jurusan di Universitas } \\
\text { katolik Parahyangan }\end{array}$ \\
\hline 7 & $\begin{array}{l}\text { Cari informasi UTBK SBMPTN Institut } \\
\text { Teknologi Bandung serta lakukan ingatkan } \\
\text { tanggal penting cara pendaftarannya, dan } \\
\text { lakukan pembersihan notifikasi. }\end{array}$ \\
\hline 8 & $\begin{array}{l}\text { Lakukan pengecekkan reminder pada tanggal } \\
\text { 20 Juni, 23 Juli, dan 25 Juli, serta lakukan } \\
\text { pengecekkan wishlist }\end{array}$ \\
\hline
\end{tabular}

Dari Tabel 6, dapat diketahu terdapat 8 tugas yang harus dikerjakan oleh responden. Untuk hasil evaluasi pertama adalah faktor usefulness. Evaluasi faktor usefulness menggunakan USE questionnaire pertanyaan 1 hingga 8. Daftar pertanyaan dapat dilihat pada Tabel 7.

Tabel 7. Daftar pertanyaan USE questionnaire

\begin{tabular}{|c|l|}
\hline No. & \multicolumn{1}{|c|}{ Pertanyaan USE questionnaire } \\
\hline 1 & $\begin{array}{l}\text { Sistem ini membantu saya menjadi lebih } \\
\text { efektif }\end{array}$ \\
\hline 2 & $\begin{array}{l}\text { Sistem ini membantu saya menjadi lebih } \\
\text { produktif }\end{array}$ \\
\hline 3 & Sistem ini bermanfaat \\
\hline 4 & $\begin{array}{l}\text { Sistem ini membantu saya terhadap tugas } \\
\text { yang saya lakukan }\end{array}$ \\
\hline 5 & $\begin{array}{l}\text { Sistem ini membuat hal-hal yang ingin saya } \\
\text { capai lebih mudah untuk dilakukan }\end{array}$ \\
\hline 6 & $\begin{array}{l}\text { Sistem ini menghemat waktu saya ketika } \\
\text { menggunakannya }\end{array}$ \\
\hline 7 & Sistem ini sesuai dengan kebutuhan saya \\
\hline 8 & $\begin{array}{l}\text { Sistem ini bekerja sesuai apa yang saya } \\
\text { harapkan }\end{array}$ \\
\hline
\end{tabular}

Dari hasil respon 7 responden, didapati hasil rata-rata USE questionnaire sebesar 81.97\%. Menurut Marthasari dan Hayatin (2017), nilai $81,97 \%$ dapat dikatakan sangat layak.

Evaluasi faktor efektivitas melihat seberapa banyak responden yang dapat menyelesaikan tugas tanpa melakukan kesalahan. 
Tabel 8. Hasil evaluasi efektivitas

\begin{tabular}{|c|c|c|c|c|}
\hline \multirow{2}{*}{ Responden } & \multicolumn{4}{|c|}{ Hasil Pengerjaan Tugas } \\
\hline & 1 & 2 & 3 & 4 \\
\hline 1 & $\sqrt{ }$ & $\sqrt{ }$ & $\sqrt{ }$ & $\sqrt{ }$ \\
\hline 2 & $\sqrt{ }$ & $\sqrt{ }$ & $\sqrt{ }$ & $\sqrt{ }$ \\
\hline 3 & $\sqrt{ }$ & $\sqrt{ }$ & $\sqrt{ }$ & $\sqrt{*}$ \\
\hline 4 & $\sqrt{ }$ & $\sqrt{*}$ & $\sqrt{ }$ & $\sqrt{ }$ \\
\hline 5 & $\sqrt{ }$ & $\sqrt{ }$ & $\sqrt{ }$ & $\sqrt{ }$ \\
\hline 6 & $\sqrt{ }$ & $\sqrt{ }$ & $\sqrt{ }$ & $\sqrt{ }$ \\
\hline 7 & $\sqrt{ }$ & $\sqrt{*}$ & $\sqrt{ }$ & $\sqrt{ }$ \\
\hline $\begin{array}{c}\text { Total } \\
\text { responden } \\
\text { mengerjak } \\
\text { an tugas } \\
\text { tanpa } \\
\text { adanya } \\
\text { kesalahan }\end{array}$ & 7 & 5 & 7 & 6 \\
\hline $\begin{array}{c}\text { Efektivitas } \\
(\%)\end{array}$ & 100 & 71,43 & 100 & 85,71 \\
\hline Resnonden & \multicolumn{4}{|c|}{ Hasil Pengerjaan Tugas } \\
\hline responden & 5 & 6 & 7 & 8 \\
\hline 1 & $\sqrt{ }$ & $\sqrt{*}$ & $\sqrt{ }$ & $\sqrt{ }$ \\
\hline 2 & $\sqrt{*}$ & $\sqrt{ }$ & $\sqrt{*}$ & $\sqrt{ }$ \\
\hline 3 & $\sqrt{ }$ & $\sqrt{ }$ & $\sqrt{ }$ & $\sqrt{ }$ \\
\hline 4 & $\sqrt{ }$ & $\sqrt{ }$ & $\sqrt{*}$ & $\sqrt{ }$ \\
\hline 5 & $\mathrm{X}$ & $\sqrt{ }$ & $\sqrt{ }$ & $\sqrt{ }$ \\
\hline 6 & $\sqrt{*}$ & $\sqrt{ }$ & $\sqrt{ }$ & $\sqrt{ }$ \\
\hline 7 & $\sqrt{ }$ & $\sqrt{ }$ & $\sqrt{ }$ & $\sqrt{*}$ \\
\hline $\begin{array}{c}\text { Total } \\
\text { responden } \\
\text { mengerjak } \\
\text { an tugas } \\
\text { tanpa } \\
\text { adanya } \\
\text { kesalahan }\end{array}$ & 4 & 6 & 5 & 6 \\
\hline $\begin{array}{c}\text { Efektivitas } \\
(\%)\end{array}$ & 57,14 & 85,71 & 71,43 & $\begin{array}{l}85, \\
71\end{array}$ \\
\hline $\begin{array}{c}\text { Rata-rata } \\
\text { Efektivitas } \\
(\%)\end{array}$ & \multicolumn{4}{|c|}{82,14} \\
\hline \multicolumn{5}{|c|}{$\begin{array}{l}\text { Keterangan } \\
\sqrt{ }=\text { Berhasil tanpa melakukan kesalahan } \\
\sqrt{ }^{*}=\text { Berhasil tetapi melakukan kesalahan } \\
\text { (dianggap gagal) } \\
X=\text { Tidak berhasil (dianggap gagal) } \\
\\
\text { Kesalahan (melakukan pemilihan tidak sesuai } \\
\text { dengan langkah-langkah pada Tabel III.14 atau } \\
\text { melakukan pemilihan yang seharusnya tidak } \\
\text { diperlukan) }\end{array}$} \\
\hline
\end{tabular}

Dari Tabel 8, dapat diketahui rata-rata efektivitas sebesar $82,14 \%$ dan dapat dinyatakan acceptable. Menurut Rubin dan Chisnell (2008), hasil evaluasi dapat dikatakan acceptable jika memiliki nilai minimum $70 \%$.

Evaluasi faktor efisiensi melihat waktu pengerjaan waktu tugas oleh responden. Waktu pengerjaan responden kemudian dibandingkan dengan waktu WPM (Waktu Pengerjaan Maksimum).

Waktu pengerjaan maksimum diperoleh dari waktu rata-rata pengerjaan tugas ketika waktu telah mencapai steady state yang ditambah dengan penyesuaian. Untuk mengetahui waktu steady state, dibutuhkan pembuatan learning curve. Contoh learning curve tugas 1 dapat dilihat pada Gambar 19.

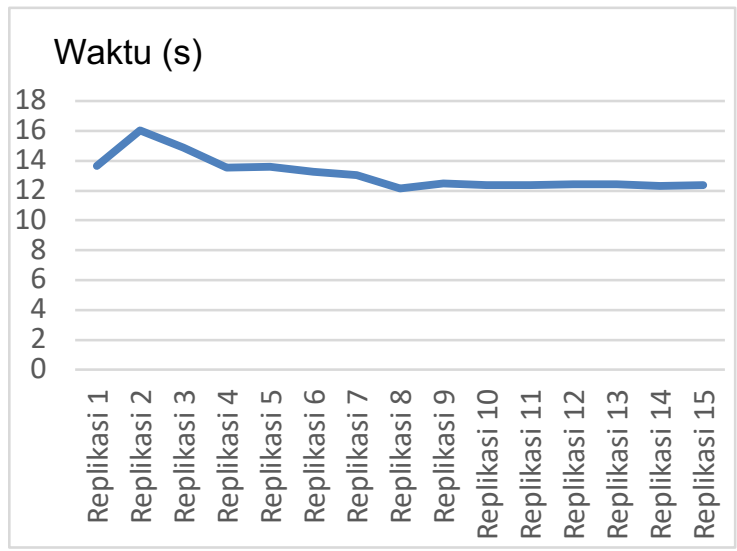

Gambar 19. Learning curve tugas 1

Dari Gambar 19, dapat diketahui jika waktu steady state terjadi mulai replikasi ke-9 hingga replikasi ke-15. Rata-rata waktu tersebut yang digunakan untuk WPM. Dalam penentuan WPM, dibutuhkan penambahan penyesuaian.

Penyesuaian menggunakan metode schumard dengan kelas excellent atau nilai 80 . Hal tersebut dikarenakan peneliti yang melakukan perancangan aplikasi dan peneliti telah mengetahui lebih baik mengenai aplikasi.

Tabel 9. WPM pengerjaan tugas

\begin{tabular}{|c|r|r|r|}
\hline Tugas & $\begin{array}{c}\text { Rata-rata } \\
\text { Waktu steady } \\
\text { state (detik) }\end{array}$ & \multicolumn{1}{l|}{$\begin{array}{l}\text { Penyes } \\
\text { uian }\end{array}$} & $\begin{array}{c}\text { WPM } \\
\text { (detik) }\end{array}$ \\
\hline 1 & 12,38 & 1,33 & 16,46 \\
\hline 2 & 23,21 & 1,33 & 30,87 \\
\hline 3 & 16,47 & 1,33 & 21,90 \\
\hline 4 & 36,57 & 1,33 & 48,64 \\
\hline 5 & 26,29 & 1,33 & 34,96 \\
\hline 6 & 23,68 & 1,33 & 31,50 \\
\hline 7 & 27,88 & 1,33 & 37,08 \\
\hline 8 & 16,42 & 1,33 & 21,84 \\
\hline
\end{tabular}

Setelah mengetahui nilai WPM pada Tabel 9, selanjutnya dilakukan perhitungan nilai efisiensi. Perhitungan efisiensi dapat dilihat pada Tabel 10.

Dari Tabel 10, dapat diketahui rata-rata efisiensi sebesar $80,36 \%$ dan dapat dinyatakan acceptable. Menurut Rubin dan Chisnell (2008), hasil evaluasi dapat dikatakan acceptable jika memiliki nilai minimum $70 \%$. 
Selanjutnya adalah hasil evaluasi faktor leanability. Evaluasi faktor learnability melihat waktu pengerjaan waktu target tugas oleh responden. Waktu pengerjaan responden tersebut kemudian dibandingkan dengan waktu WPM (Waktu Pengerjaan Maksimum).

Tabel 10. Hasil evaluasi efisiensi

\begin{tabular}{|c|c|c|c|c|}
\hline \multirow[t]{2}{*}{ Responden } & \multicolumn{4}{|c|}{$\begin{array}{l}\text { Waktu Pengerjaan Tugas } \\
\text { (detik) }\end{array}$} \\
\hline & 1 & 2 & 3 & 4 \\
\hline 1 & 17,92 & 17,11 & 15,37 & 37,35 \\
\hline 2 & 34,07 & 42,56 & 18,94 & 41,79 \\
\hline 3 & 11,36 & 26,89 & 18,69 & 33,63 \\
\hline 4 & 18,87 & 37,96 & 19,47 & 36,68 \\
\hline 5 & 13,14 & 23,77 & 14,79 & 32,72 \\
\hline 6 & 12,7 & 20,56 & 14,16 & 34,88 \\
\hline 7 & 15,57 & 21,33 & 14,6 & 58,67 \\
\hline WPM (detik) & 16,46 & 30,87 & 21,9 & 48,64 \\
\hline $\begin{array}{l}\text { Total } \\
\text { responden } \\
\text { berhasil }\end{array}$ & 4 & 5 & 7 & 6 \\
\hline Efisiensi (\%) & 57,14 & 71,43 & 100 & 85,71 \\
\hline \multirow[t]{2}{*}{ Responden } & \multicolumn{4}{|c|}{$\begin{array}{l}\text { Waktu Pengerjaan Tugas } \\
\text { (detik) }\end{array}$} \\
\hline & 5 & 6 & 7 & 8 \\
\hline 1 & 22,71 & 24,74 & 23,07 & 20,53 \\
\hline 2 & 46,48 & 25,08 & 33,32 & 24,78 \\
\hline 3 & 26,53 & 24,97 & 27,77 & 16,01 \\
\hline 4 & 25,95 & 30,44 & 55,17 & 16,21 \\
\hline 5 & 35,28 & 28,87 & 26,32 & 17,72 \\
\hline 6 & 26,65 & 23,47 & 23,81 & 19,32 \\
\hline 7 & 49,05 & 28,94 & 28,93 & 20,67 \\
\hline WPM (detik) & 34,96 & 31.5 & 37,08 & 21,84 \\
\hline $\begin{array}{l}\text { Total } \\
\text { responden } \\
\text { berhasil }\end{array}$ & 4 & 7 & 6 & 6 \\
\hline Efisiensi (\%) & 57,14 & 100 & 85,71 & 85,71 \\
\hline $\begin{array}{c}\text { Rata-rata } \\
\text { Efisiensi (\%) }\end{array}$ & \multicolumn{4}{|c|}{80,36} \\
\hline
\end{tabular}

Sedangkan daftar target tugas dapat dilihat pada Tabel 11.

Tabel 11. Daftar target tugas

\begin{tabular}{|c|l|}
\hline No. & \multicolumn{1}{|c|}{ Target Tugas } \\
\hline 1 & $\begin{array}{l}\text { Lakukan ingatkan tanggal penting } \\
\text { pendaftaran UNPAR }\end{array}$ \\
\hline 2 & Lakukan pencarian beasiswa Tokopedia \\
\hline 3 & $\begin{array}{l}\text { Lakukan pencarian testimoni lulusan Teknik } \\
\text { Industri UNPAR }\end{array}$ \\
\hline 4 & $\begin{array}{l}\text { Lakukan pencarian jurusan Teknik Sipil } \\
\text { terbaik di Jawa Tengah }\end{array}$ \\
\hline 5 & $\begin{array}{l}\text { Lakukan pengecekkan obrolan dengan } \\
\text { Dian Budiawan }\end{array}$ \\
\hline
\end{tabular}

Sama halnya dengan faktor efisiensi, perhitungan faktor learnability membutuhkan WPM. Perhitungan WPM membutuhkan ratarata waktu steady state dan nilai penyesuaian. Penentuan rata-rata waktu steady state menggunakan cara yang sama seperti Gambar 18 (menggunakan learning curve). Untuk penyesuaian yang digunakan adalah excellent dengan nilai 80 . Nilai WPM target tugas dapat dilihat pada Tabel 12.

Setelah mengetahui nilai WPM pada Tabel 9, selanjutnya dilakukan perhitungan nilai learnability. Perhitungan learnability dapat dilihat pada Tabel 13.

Tabel 12. WPM pengerjaan target tugas

\begin{tabular}{|c|r|r|r|}
\hline Tugas & $\begin{array}{c}\text { Rata-rata } \\
\text { Waktu } \\
\text { steady state } \\
\text { (detik) }\end{array}$ & Penyesuaian & $\begin{array}{c}\text { Waktu } \\
\text { Pengerjaan } \\
\text { Maksimum } \\
\text { (WPM) (detik) }\end{array}$ \\
\hline 1 & 13,69 & 1,33 & 18,21 \\
\hline 2 & 7,58 & 1,33 & 10,08 \\
\hline 3 & 13,01 & 1,33 & 17,31 \\
\hline 4 & 12,85 & 1,33 & 17,10 \\
\hline 5 & 5,01 & 1,33 & 6,66 \\
\hline
\end{tabular}

Tabel 13. Hasil evaluasi learnability

\begin{tabular}{|c|c|c|c|}
\hline \multirow[t]{2}{*}{ Responden } & \multicolumn{3}{|c|}{$\begin{array}{c}\text { Waktu Pengerjaan Target } \\
\text { (detik) }\end{array}$} \\
\hline & 1 & 2 & 3 \\
\hline 1 & 15,3 & 6,55 & 13,84 \\
\hline 2 & 21,46 & 9,6 & 15,86 \\
\hline 3 & 14,49 & 17,05 & 15,85 \\
\hline 4 & 27,38 & 10,22 & 21,56 \\
\hline 5 & 7,22 & 6,98 & 14,18 \\
\hline 6 & 17,23 & 8,15 & 14,98 \\
\hline 7 & 26,45 & 10,32 & 15,73 \\
\hline WPM (detik) & 18,21 & 10,08 & 17,31 \\
\hline $\begin{array}{c}\text { Total responden } \\
\text { berhasil }\end{array}$ & 4 & 4 & 6 \\
\hline Learnability (\%) & 57,14 & 57,14 & 85,71 \\
\hline \multirow[t]{2}{*}{ Responden } & \multicolumn{3}{|c|}{$\begin{array}{l}\text { Waktu Pengerjaan Target } \\
\text { (detik) }\end{array}$} \\
\hline & 4 & 5 & \\
\hline 1 & Salah & 10,19 & \\
\hline 2 & 15,15 & 5,04 & \\
\hline 3 & 14,98 & 4,98 & \\
\hline 4 & 16,78 & 6,53 & \\
\hline 5 & Salah & 6,15 & \\
\hline 6 & 14,25 & 6,23 & \\
\hline 7 & 16,43 & 6,02 & \\
\hline WPM (detik) & 17,1 & 6,66 & \\
\hline $\begin{array}{c}\text { Total responden } \\
\text { berhasil }\end{array}$ & 5 & 6 & \\
\hline Learnability (\%) & 71,43 & 85,71 & \\
\hline $\begin{array}{c}\text { Rata-rata } \\
\text { learnability (\%) }\end{array}$ & \multicolumn{3}{|c|}{71,43} \\
\hline
\end{tabular}

Menurut Rubin dan Chisnell (2008), hasil evaluasi dapat dikatakan acceptable jika memiliki nilai minimum $70 \%$, sehingga ratarata learnability sebesar $71,43 \%$ dan dapat dinyatakan acceptable.

Selanjutnya adalah hasil evaluasi faktor satisfaction. Evaluasi faktor satisfaction melihat 
pendapat, perasaan, dan opini pengguna terhadap aplikasi. hal tersebut dapat dinilai dengan menggunakan kuesioner SUS (System Usability Scale). Terdapat 11 pertanyaan SUS yang dapat dilihat pada Tabel 14.

Tabel 14. Pertanyaan SUS (System Usability Scale)

\begin{tabular}{|c|l|}
\hline No. & \multicolumn{1}{|c|}{ Pertanyaan SUS } \\
\hline 1 & $\begin{array}{l}\text { Saya sepertinya akan sering menggunakan } \\
\text { aplikasi ini }\end{array}$ \\
\hline 2 & $\begin{array}{l}\text { Saya meihat ada bagian fitur aplikasi yang } \\
\text { cukup rumit yang semestinya hal itu tidak } \\
\text { perlu terjadi. }\end{array}$ \\
\hline 3 & $\begin{array}{l}\text { Saya rasa aplikasi ini mudah untuk } \\
\text { digunakan. }\end{array}$ \\
\hline 4 & $\begin{array}{l}\text { Saya rasa saya akan butuh bantuan dari } \\
\text { teknisi yang ahli untuk bisa menggunakan } \\
\text { aplikasi ini dengan lancar. }\end{array}$ \\
\hline 5 & $\begin{array}{l}\text { Saya rasa fitur-fitur dalam aplikasi sudah } \\
\text { terintegrasi dengan baik. }\end{array}$ \\
\hline 6 & $\begin{array}{l}\text { Saya menemukan banyak hal yang tidak } \\
\text { konsisten dalam aplikasi. }\end{array}$ \\
\hline 7 & $\begin{array}{l}\text { Saya pikir banyak orang yang bisa } \\
\text { menggunakan aplikasi ini dengan sangat } \\
\text { cepat. }\end{array}$ \\
\hline 8 & $\begin{array}{l}\text { Saya merasa aplikasi ini sangat sulit untuk } \\
\text { digunakan. }\end{array}$ \\
\hline 9 & $\begin{array}{l}\text { Saya merasa sangat percaya diri dalam } \\
\text { menggunakan aplikasi ini. }\end{array}$ \\
\hline 10 & $\begin{array}{l}\text { Saya harus mempelajari banyak hal sebelum } \\
\text { menggunakan aplikasi ini. }\end{array}$ \\
\hline
\end{tabular}

Dari hasil respon 7 responden, didapati hasil rata-rata nilai SUS sebesar $79,64 \%$ dan dikategorikan baik menurut Alathas (2018).

Evaluasi kualitatif melihat 3 hal, yaitu kesalahan yang dilakukan responden ketika menjalankan tugas, penyebab responden lama dalam menjalankan tugas, dan hasil wawancara terstruktur. Wawancara terstruktur dilakukan setelah responden selesai mengerjakan tugas yang diberikan.

Terdapat 6 pertanyaan yang ditanyakan kepada responden dalam wawancara terstruktur. Pertanyaan tersebut dapat dilihat pada Tabel 15.

Tabel 15. Pertanyaan wawancara terstruktur

\begin{tabular}{|c|l|}
\hline No. & \multicolumn{1}{|c|}{ Pertanyaan } \\
\hline 1 & $\begin{array}{l}\text { Bagaimana ukuran tulisan untuk prorotipe } \\
\text { aplikasi? Apakah sudah terbaca? }\end{array}$ \\
\hline 2 & $\begin{array}{l}\text { Bagaimana pemilihan warna untuk prototipe } \\
\text { aplikasi? Apakah sudah menarik bagi } \\
\text { kalangan pelajar SMA/ mahasiswa? }\end{array}$ \\
\hline 3 & $\begin{array}{l}\text { Bagaimana dengan kontras warna? Apakah } \\
\text { warna tulisan background sudah sesuai dan } \\
\text { tulisan dapat dengan mudah dibaca? }\end{array}$ \\
\hline
\end{tabular}

Tabel 15. Pertanyaan wawancara terstruktur (lanjutan)

\begin{tabular}{|c|l|}
\hline No. & \multicolumn{1}{|c|}{ Pertanyaan } \\
\hline 4 & $\begin{array}{l}\text { Bagaimana dengan ukuran tombol? Apakah } \\
\text { ada ukuran tombol yang kekecilan atau } \\
\text { terlalu besar? }\end{array}$ \\
\hline 5 & $\begin{array}{l}\text { Bagaimana dengan informasi yang diberikan } \\
\text { oleh aplikasi? Apakah sudah cukup lengkap } \\
\text { dan sesuai? }\end{array}$ \\
\hline 6 & $\begin{array}{l}\text { Dari penggunaan prototipe aplikasi tadi, } \\
\text { apakah ada kendala yang dihadapi atau hal- } \\
\text { hal yang perlu diperbaiki dari aplikasi? }\end{array}$ \\
\hline
\end{tabular}

Dapat dilihat pertanyaan wawancara terstruktur pada Tabel 12. Untuk pertanyaan 1 hingga 5 , hanya pertanyaan 4 yang responden tidak setujui. Responden mengatakan jika ukuran tombol terlalu kecil dan perlu dilakukan perbaikan. Respon responden pertanyaan 6 dapat dilihat pada Tabel 16.

Tabel 16. Respon responden pertanyaan 6

\begin{tabular}{|c|c|c|}
\hline $\begin{array}{c}\text { Res- } \\
\text { ponden }\end{array}$ & $\begin{array}{c}\text { Pernyataan } \\
\text { baru }\end{array}$ & $\begin{array}{c}\text { Rekapitulasi Hasil } \\
\text { Pernyataan Responden }\end{array}$ \\
\hline \multirow{5}{*}{1} & 1 & Tombol terlalu kecil \\
\hline & 2 & $\begin{array}{l}\text { Beberapa tombol tidak } \\
\text { 85esponsive (harus dicoba } \\
\text { berkali-kali) }\end{array}$ \\
\hline & 3 & $\begin{array}{l}\text { tulisan atau huruf numpuk di } \\
\text { profil perguruan tinggi } \\
\text { (tampilan di beberapa } \\
\text { halaman kurang rapi) }\end{array}$ \\
\hline & 4 & Bagian bawah suka ilang \\
\hline & 5 & $\begin{array}{l}\text { Tadi ada halaman yang } \\
\text { susah di scroll (Contohnya } \\
\text { halaman pendaftaran) }\end{array}$ \\
\hline \multirow[b]{2}{*}{2} & 1 & $\begin{array}{l}\text { kolom pilihan perbandingan } \\
\text { jurusan kekecilan }\end{array}$ \\
\hline & 2 & $\begin{array}{l}\text { Tugas-tugasnya sulit } \\
\text { dimengerti, terlalu panjang, } \\
\text { dan sering kali lupa } \\
\text { instruksinya }\end{array}$ \\
\hline \multirow[t]{2}{*}{3} & 1 & $\begin{array}{l}\text { Tombol UI terkadang } \\
\text { muncul overlay biru ketika } \\
\text { ditekan }\end{array}$ \\
\hline & 2 & $\begin{array}{l}\text { Kolom search yang terpisah } \\
\text { seringkali membingungkan }\end{array}$ \\
\hline \multirow[t]{2}{*}{4} & 1 & $\begin{array}{l}\text { Pada bagian pendaftaran } \\
\text { unpar, notif tertimpa layer } \\
\text { atas (beberapa hal saling } \\
\text { tindih) }\end{array}$ \\
\hline & 2 & $\begin{array}{l}\text { Pada bagian jurusan, tab } \\
\text { bawah lebih naik }\end{array}$ \\
\hline 5 & 1 & $\begin{array}{l}\text { Mustinya bisa di back kaya } \\
\text { pake back hp }\end{array}$ \\
\hline
\end{tabular}

Untuk meningkatkan nilai usability dan menanggapi hasil penilaian kualitatif maka 
dilakukan perbaikan pada prototipe aplikasi penyedia informasi perguruan tinggi. Perbaikan pertama dapat dilihat pada Gambar 20.

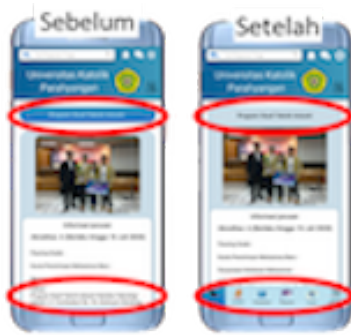

Gambar 20. Perbaikan pertama prototipe aplikasi

Dapat dilihat pada Gambar 20, sebelum dan setelah perbaikan. Perbaikan yang dilakukan adalah menghilangkan latar kotak untuk tulisan "program studi Teknik industri" dan menambahkan tab menu bagian bawah.

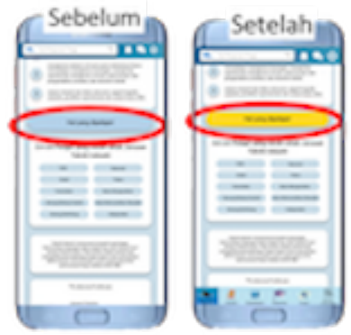

Gambar 21. Perbaikan kedua prototipe aplikasi

Dapat dilihat pada Gambar 21, sebelum dan setelah perbaikan. Perbaikan yang dilakukan adalah mengubah warna latar kotak pada "hal yang dipelajari" menjadi lebih kontras.

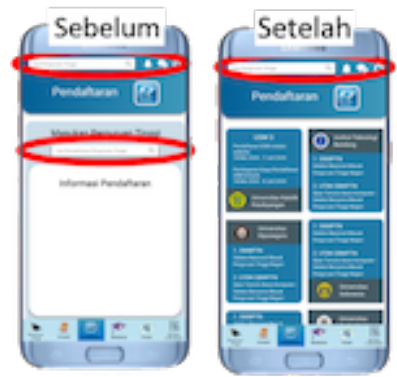

Gambar 22. Perbaikan ketiga prototipe aplikasi

Dapat dilihat pada Gambar 22, sebelum dan setelah perbaikan. Perbaikan yang dilakukan adalah menggabungkan kolom search menjadi 1 pada bagian atas. Penggabungan kolom search dilakukan untuk tab menu utama pendaftaran dan beasiswa. Terdapat beberapa perbaikan lain yang tidak ditampilkan, seperti ukuran tombol yang diperbesar, memperbaiki permasalahan tampilan yang tidak dapat dilakukan scroll, dan lainnya.

\section{Analisis}

\section{Keterlibatan Pihak Perguruan Tinggi}

Penelitian yang dilakukan hanya melibatkan pelajar SMA/ sederajat kelas 2 dan kelas 3, pelajar yang ingin melanjutkan pendidikan ke perguruan tinggi, dan Mahasiswa salah jurusan. Dalam penelitian tidak melibatkan pihak perguruan tinggi dalam proses apapun. Untuk proses identifikasi kebutuhan, pihak perguruan tinggi tidak dilibatkan karena perancangan aplikasi berfokus primary user (pelajar SMA/ sederajat kelas 2 dan kelas 3, pelajar yang ingin melanjutkan pendidikan ke perguruan tinggi, dan Mahasiswa salah jurusan).

Pada proses perancangan aplikasi, pihak perguruan tinggi tidak dilibatkan karena pihak perguruan tinggi tidak menjadi user. Apabila pihak perguruan tinggi menjadi sumber penyedia informasi, aplikasi yang digunakan oleh pihak perguruan tinggi akan berbeda. Hal tersebut menjadi pertimbangan tidak melibatkan pihak perguruan tinggi dalam perancangan aplikasi.

Untuk saat ini, pihak perguruan tinggi tidak terlibat dalam penelitian. Jika terdapat perkembangan lebih lanjut dari aplikasi, sebaiknya pihak perguruan tinggi dilibatkan menjadi sumber penyedia informasi perguruan tinggi.

\section{Penentuan kebutuhan}

Penentuan kebutuhan sebaiknya terdapat 2 kelompok lebih dalam melakukan focus group discussion, untuk menghasilkan kebutuhan yang lebih banyak. Fasilitator pada focus group discussion sebaiknya yang tegas, supaya kegiatan focus group discussion dapat berjalan sesuai tujuan.

\section{Perancangan Alternatif Desain}

Perancangan metode participatory design workshop. Dalam penelitian pelaksanaan dilakukan secara daring menggunakan bantuan media zoom. Participatory design workshop secara daring memiliki beberapa kesulitan, seperti responden yang telat hadir, gangguan koneksi internet, dan lainnya. 
Dalam perancangan, peneliti/ designer ikut terlibat. Keterlibatan dimulai dengan penjelasan mengenai tujuan participatory design workshop, memberikan penjelasan dan contoh dari alternatif desain, responden dapat bertanya jika mengalami kendala dalam perancangan, dan keterlibatan lainnya.

\section{Pemilihan Alternatif Desain Terpilih}

Alternatif desain lebih difokuskan pada hasil kuantitatif, karena penilaian kualitatif hanya dilakukan oleh peneliti sedangkan kuantitatif dilakukan oleh responden sebagai calon user.

\section{Prototipe Aplikasi}

Perancangan prototipe aplikasi menggunakan aplikasi adobe XD. Jika dilihat warna dominan aplikasi adalah biru. Warna biru dipilih karena melambangkan pendidikan. Ukuran tulisan, tombol, dan lainnya telah disesuaikan berdasarkan referensi adobe XD.

Seperti telah diketahui, terdapat beberapa fitur dari aplikasi. fitur-fitur tersebut disesuaikan dengan seluruh kebutuhan pengguna yang diperoleh pada tahapan penentuan kebutuhan.

Dalam menjalankan prototipe, dapat dilakukan dengan 2 cara, pertama dengan aplikasi adobe $X D$ dan kedua dengan menggunakan link shared adobe XD. Masingmasing cara memiliki kelebihan dan kekurangan. Kelebihan menggunakan link shared adobe XD adalah lebih sederhana, tampilan sama seperti prototipe aslinya, dapat melakukan back menggunakan back smartphone, dan tidak adanya layer biru ketika pemilihan tidak akurat. Kekurangan menggunakan link shared adobe XD, harus memiliki koneksi internet yang cepat. Penggunaan aplikasi adobe XD merupakan kebalikan dari link shared adobe XD.

\section{Evaluasi Usability Kuantitatif}

Pada hasil evaluasi usefulness, terdapat responden yang memberikan nilai 2 (buruk) terhadap pertanyaan "sistem ini bekerja sesuai apa yang saya harapkan" hal tersebut dapat terjadi karena kurang konsistennya aplikasi. Pernyataan tersebut didukung dari hasil evaluasi faktor satisfaction, yang menunjukkan responden memberikan nilai tinggi untuk pertanyaan "saya menemukan banyak hal yang tidak konsisten dalam aplikasi". Untuk saat ini telah dilakukan perbaikan terhadap aplikasi menjadi lebih konsisten.

\section{Evaluasi Usability Kualitatif}

Ketika melihat responden mengerjakan tugas, sebenarnya kesalahan responden ada yang tidak berasal dari prototipe aplikasi. kesalahan responden berasal dari tugas yang terlalu panjang atau tugas yang ambigu. Peneliti melihat, responden berpikir dan berusaha mengingat tugas yang diminta. Kesalahan ini tidak dapat dilakukan perbaikan pada penelitian ini, tapi dapat menjadi pertimbangan pada penelitian selanjutnya.

\section{Perbaikan Prototipe}

Perbaikan prototipe dilakukan berdasarkan kesalahan responden dalam melakukan tugas, lama responden menyelesaikan tugas, dan hasil wawancara terstruktur. Perbaikan yang dilakukan meliputi ukuran tombol yang diperbesar, penggabungan kolom search, memperbaiki tampilan sehingga lebih konsisten, memperbaiki permasalahan scroll, memperbaiki tampilan menumpuk pada aplikasi, dan mengubah beberapa kontras warna pada prototipe aplikasi.

\section{Kesimpulan}

Perancangan aplikasi berfokus pada kebutuhan pengguna. Hal tersebut dapat dilihat pada proses penilaian kuantitatif alternatif desain. Pada penilaian kuantitatif, penilaian berdasarkan kebutuhan pengguna. Dikarenakan kebutuhan pengguna menjadi dasar perancangan aplikasi penyedia informasi perguruan tinggi, maka rancangan aplikasi dapat dikatakan dapat membantu pelajar SMA/ sederajat untuk mengakses informasi yang dibutuhkan.

Rancangan aplikasi yang terbentuk telah memenuhi aspek functionality dan juga aspek usability. Aspek functionality dilihat dari fungsi aplikasi yang telah berjalan sesuai dengan tujuannya. Hal ini dibuktikan melalui usability testing, tepatnya ketika pengguna dapat menggunakan prototipe aplikasi untuk menyelesaikan tugas yang diberikan dan dari hasil wawancara terstruktur pengguna mengatakan informasi yang diberikan aplikasi sudah lengkap dan sesuai.

Aspek usability aplikasi dilihat dari hasil penilaian 5 faktor usability (usefulness, efektivitas, efisiensi, learnability, dan satisfaction). Hasil evaluasi usefulness 
memiliki nilai $81,79 \%$, efektivitas memiliki nilai $82,14 \%$, efisiensi memiliki nilai $80,36 \%$, learnability memiliki nilai $71,43 \%$, dan satisfaction memiliki nilai $79,64 \%$. Menurut referesi, untuk nilai usability diatas $70 \%$ dapat dinyatakan acceptable. Dikarenakan penilaian aplikasi dikatakan acceptable, maka rancangan aplikasi penyedia informasi perguruan tinggi dapat dikatakan telah memenuhi aspek usability.

\section{Daftar Pustaka}

Sekaran, U. (2010). Research Methods for Business. Chichester: John Wiley \& Sons.

Sudarwati, W., \& Tikwalau, D. E. (2014). Faktor-Faktor yang Mempengaruhi SiswaSiswa SMU/ SMK Terhadap Keputusan Pemilihan Perguruan Tinggi Swasta.

Rubin, J., \& Chisnell, D. (2008). Handbook of Usability Testing 2nd Ed. Canada: Wiley Publishing INC.

Jordan, W. P. (2000). designing Pleasurable products: an introduction to the new human factor. London: Taylor \& Francis Books Ltd.

Sakai, T., Okuyama, J., Arai, N., Nakamura, Y., Tsuji, T., Moriya, K., . . . Hishiyama, R. (2012). Field Informatics. In T. Ishida, Filend Informatics (pp. 123-133). Kyoto: Springer-Verlag Berlin Heidelberg.

Demirbilek, O. (1999). Involving The Elderly In The Design Process: a Participatoy Design Model For Usability Safety and Attractivenss.

Preece, J., Sharp, H., \& Rogers, Y. (2015). Interaction Design: Beyond HumanComputer Interaction 4th ed. United Kingdom: John Wiley \& Sons Ltd.

Moran, K. (2019, Desember 1). Usability Testing 101. Retrieved from Nielsen Norman Group: https://www.nngroup.com/articles/usabilitytesting-101/

Brooke, J. (2013). SUS: A Retrospective. JUS Journal Of Usability Studies, 29-40.

Thomas, N. (2013). How To Use The System Usability Scale (SUS) To Evaluate The Usability Of Your Website. Retrieved from UsabilityGeek: https://usabilitygeek.com/how-to-use-thesystem-usability-scale-sus-to-evaluate-theusability-of-your-website/

Afiyanti, Y. (2008). Focus Group Discussion (Diskusi Kelompok Terfokus) Sebagai Metode Pengumpulan Data Penelitian Kualitatif. Keperawatan Indonesia, 58-62.

Paramita, A., \& Kristiana, L. (2013). Teknik Focus Group Discussion Dalam Penelitian Kualitatif (Focus Group Discussion Tehnique in Qualitative Reseach). Buletin Penelitian Sistem Kesehatan, 117-127.

Marthasari , G. I., \& Hayatin, N. (2017). Analisis Usability Terhadap Sistem Lective Gegulang Berbasis USE Questionnaire. Seminar Nasional Teknologi dan Rekayasa (Sentra) 2017.

Putri, N. (2018, April 14). Youthmanual: Angka Siswa yang SAlah Pilih Jurusan Masih Tinggi. Retrieved from Skystar Ventures: http://www.skystarventures.com/youthmanu al-angka-siswa-yang-salah-pilih-jurusanmasih-tinggi/

Dekirty, X. (2019, Agustus 17). 5 Penyebab Mengapa Mahasiswa Masih Salah Ambil Jurusan. Retrieved from IDN Times Web Site:

https://www.idntimes.com/life/education/xeh i-dekirty/penyebab-mahasiswa-masihsalah-ambil-jurusan-kuliah-exp-c1c2/full

KOMINFO. (2017). Survei Penggunaan TIK Tahun 2017, 19.

Putra, Y. S., \& Tanamal, R. (2020). Analisis Usability Menggunakan Metode USE Questionnaire Pada Website Ciputra Enterprise System. TEKNIKA, 58-65.

Sutalaksana, I. Z., Anggawisastra, \& Tjakraatmadja. (2016). Teknik Perancangan Sistem Kerja. Bandung: Laboratorium Tata Cara Kerja \& Ergonomi, Departemen Teknik Industri ITB.

Christina, S., Hardiandja, J., \& Nainggolan, M. (2014, April 30). Perancangan Aplikasi Penunjang Aktivitas Travelling yang Interaktif dan Mobile untuk Paruh baya Menggunakan Teknik Cooperative Prototyping. Jurnal Rekayasa Sistem Industri, 03(01). 